\title{
Preparing multicomponent snack bars based on tapioca flour, Brazil nut, and regional fruits
}

\section{Preparación de barras multicomponentes a base de harina de tapioca, castaña de brasil y frutos regionales}

\section{ABSTRACT}

This study aimed to develop and assess the physicochemical, sensory parameters, and shelf life estimation of multicomponent snack bars based on tapioca flour, Brazil nut, and açaí or cupuassu pulp. The physicochemical composition of açaí- and cupuassu-flavored snack bars had, respectively, 0.92 and $0.99 \%$ ash, 19.22 and $17.02 \%$ lipids, 3.02 and $3.03 \%$ protein, 1.06 and $1.69 \%$ fiber, and 448 and $436 \mathrm{kcal} / 100 \mathrm{~g}$ energy value. The shear stress test showed the consumer needs to bite more strongly to break the açai-flavored bar. The opposite was observed in the hardness test, in which the bite compression force during mastication was greater for the cupuassu-flavored bar. The bars had water activity below 0.6, which denotes microbiological stability. The sensory analysis ranked the bars between "liked slightly" and "liked very much," which was confirmed by the acceptability index above $75 \%$ for all attributes assessed. According to the results a significant increase in water activity over storage was observed suggest the packaging used in the tests did not present a satisfactory barrier to water vapor permeability. Only water activity was used to estimate shelf life, which was determined as 58 days and 49 days for the açaí- and cupuassu-flavored bars, respectively. Thus, the snack bars represent an alternative for athletes as well as individuals with celiac disease since they are gluten free.

Keywords: Açaí; Brazil nut; Cupuassu; Multicomponent snack bars; Tapioca flour.

\section{RESUMEN}

El objetivo de este trabajo fue desarrollar y evaluar los parámetros físicos, físico-químicos, microbiológicos, sensoriales y la vida útil en estante de barras a base de harina de tapioca, castaña de Brasil y pulpa de açaí o cupuaçu. En cuanto a la composición físico-química, las barras multicomponentes sabor açaí y cupuaçu presentaron, respectivamente, 0,92 y 0,99\% de cenizas, 19,22 y 17,02\% de lípidos, 3,02 y 3,03\% proteínas, 1,06 y 1,69\% de fibras y 448 y 436 kcal/100g de valor energético. La prueba de cizallamiento y dureza mostraron que el consumidor necesita una fuerza de mordida mayor para romper la barra
Isadora Cordeiro dos Prazeres ${ }^{1}$, Ana Vânia Carvalho ${ }^{2 *}$, Alessandra Ferraiolo Nogueira Domingues², Laura Figueiredo $\mathrm{Abreu}^{2}$.

1. Federal University of Pará (UFPA), Belém, PA, Brazil. 2. Embrapa Eastern Amazon Research Center, Food Processing Laboratory, Belém, PA, Brazil.

*Corresponding author: Ana Vânia Carvalho. Federal University of Pará (UFPA), Augusto Corrêa Street, n. 01, CEP 66075-110, Belém, PA, Brazil. E-mail: ana-vania.carvalho@embrapa.br

Este trabajo fue recibido el 17 de enero de 2019. Aceptado con modificaciones: 20 de mayo de 2019. Aceptado para ser publicado: 01 de agosto de 2019.

sabor açaí. El comportamiento contrario fue observado en la prueba de dureza donde la fuerza de compresión de la mordida, durante la masticación, fue mayor en la barra sabor cupuaçu. Para el análisis sensorial se observó que las barras evaluadas recibieron notas situadas entre las categorías "me gustó ligeramente" y "me gustó mucho", resultado comprobado por el índice de aceptabilidad con valores superiores al $75 \%$ para todos los atributos evaluados. De acuerdo con los resultados, se observó un aumento significativo en la actividad de agua durante el almacenamiento, lo que sugiere que el embalaje utilizado en las pruebas no presentó una barrera satisfactoria para la permeabilidad al vapor de agua. Para la estimación de vida de estante sólo la actividad de agua fue utilizada para 
los cálculos, siendo el tiempo de vida de estante determinado en 58 días para la barra sabor açaí y 49 días para la barra sabor cupuaçu. Así, las barras multicomponentes elaboradas representam una alternativa para atletas, así como para portadores de la enfermedad celíaca, visto la ausencia de gluten en su composición.

Palabras clave: Barras multicomponentes; Baya Acaí; Castaña de Brasil ; Cupuacu; Harina de tapioca.

\section{INTRODUCTION}

Over the past decades, there has been growing interest in products that, besides basic nutrition, promote benefits to health. That places certain foods and ingredients on the list of preferences of an increasingly larger number of consumers ${ }^{1}$.

Cereal bars were launched in the market as an alternative for people seeking a healthy diet. Those bars were introduced in Brazil around two decades ago and were, initially, targeted at athletes and, over time, the audience grew and appealed to businesspeople. Cereal bars are popular as portable food and can be consumed between meals or along with lunch or dinner. They are a nutritive food made up of several ingredients, including cereals, fruits, nuts, and sugar ${ }^{2,3,4}$. Some commercially available cereal bars are crunchy, savory, fruit- and chocolate-flavored, filled, functional, light, and diet ${ }^{3}$.

Multicomponent foods are those which, in their composition, are very complex and must be properly combined to guarantee the ingredients complement each other regarding flavor, texture, and physical properties, particularly concerning water activity equilibrium ${ }^{5}$. Cereal bars are examples of such multicomponent foods ${ }^{3}$.

Given the high demand for gluten-free foods, many companies are redesigning the ingredients in their products to satisfy the needs of consumers ${ }^{6}$. Glutenrelated disorders are triggered in certain individuals when products that contain gluten are consumed ${ }^{7}$. Gluten-free diet represents the treatment for celiac disease, non-celiac gluten sensitivity and wheat allergy. Another group of persons that follow a gluten-free diet has emerged, persons that perceive this diet as a healthier eating habit. It is especially this latter group that has increased to such an extent that they have modified the market for gluten-free foods, improving availability of these products ${ }^{8}$.

Tapioca flour is a product derived from cassava flour and is widely consumed in the Amazon. It is naturally classified as a gluten-free food ${ }^{9,10}$.

From a nutritional standpoint, the Brazil nut is an excellent source of essential nutrients for organic balance. It has a high content of total lipids (60-70\%), unsaturated lipids (14-56\%), protein (15-20\%), and selenium (0.03$0.52 \mathrm{mg} / 100 \mathrm{~g})^{11,12}$.

Açaí berries have a significant amount of bioactive compounds and have attracted interest from the food industry for the development of functional products, which has increased its production and commercialization, including in international markets ${ }^{13}$.

Cupuassu is a commercial crop from the Northern region of Brazil and stands out for the sensory characteristics of its pulp which has various uses and, as such, has excellent conditions for employment by the food industry ${ }^{14}$.

In view of the economic and social importance of the cassava productive chain in the Northern region of Brazil and the nutritional characteristics and functional properties of the Brazil nut, açaí, and cupuassu, this study aimed to develop and assess the physicochemical, sensory parameters, and shelf life estimation of multicomponent snack bars based on tapioca flour, Brazil nut, and açaí or cupuassu pulp.

\section{MATERIAL AND METHODS Material}

The tapioca flour (subclass granulated, type 1) and Brazil nut used to prepare the multicomponent snack bars were purchased from local producers in Belém, PA, Brazil. The other ingredients were purchased in commercial markets.

The binding syrup comprised refined sugar (União, Brazil), glucose syrup (Arcolor, Brazil), maltodextrin (Athletica, Brazil), bidistilled glycerin (Arcolor, Brazil), soy lecithin (Gastronomy Lab, Brazil), palm fat 370 B (Agropalma - Companhia Refinadora da Amazônia, Brazil), and açaí (Iaçá, Brazil) or cupuassu (Camta, Brazil) pulp according to the flavor of the multicomponent snack bar.

For the shelf life assay, the snack bars were packaged in laminated BOPP (biaxially oriented polypropylene)/ metalized BOPP (Copobras Descartáveis Ltda, Brazil).

\section{Methods \\ Formulation and preparation of multicomponent snack bars}

The açaí- and cupuassu-flavored multicomponent snack bars were prepared at the Agro-Industry Laboratory of Embrapa Eastern Amazon (Belém, PA, Brazil).

Based on some scientific papers available in the literature ${ }^{2,15,16,17}$, preliminary tests were carried out with varying ingredient concentrations in order to establish a base formulation for the multicomponent snack bars. This formulation was defined by the best cohesion among the ingredients.

The binding syrup was prepared under heating and stirring in a stainless steel container and the total soluble solids content was monitored using an $\mathrm{ABBE}$ CIELAB (model REFAB-1000S, BioBrix, Brazil) digital refractometer until $85-89^{\circ} \mathrm{Brix}$. Next, the dry ingredients were added to the syrup $\left(95^{\circ} \mathrm{C}\right)$ and the mix was placed on a mold, pressed, and left to sit at room temperature. After the mixture cooled down, it was removed from the mold and cut into $6.5 \times 3 \times 1.5 \mathrm{~cm}$ pieces with a stainless steel knife. The bars, each weighing around 
$25 \mathrm{~g}$, were individually packaged in BOPP/metalized BOPP film. Table 1 presents the formulations of the multicomponent snack bars studied.

Table 1. Dry ingredients and binding agents used in the formulation of multicomponent snack bars.

\begin{tabular}{|lcc|}
\hline Ingredients & Formulations & \\
\hline & Açaí bar (\%) & Cupuassu bar (\%) \\
\hline Tapioca flour & 27 & 25 \\
Brazil nut & 14 & 13 \\
Fruit pulp & 15 & 20 \\
Glycerin & 2.5 & 2 \\
Sugar & 11.5 & 10 \\
Maltodextrin & 7 & 6 \\
Glucose syrup & 15 & 17 \\
Soy lecithin & 2 & 2 \\
Palm fat & 6 & 5 \\
\hline
\end{tabular}

\section{Physicochemical characterization}

Moisture, protein, lipid, and ash content were determined according to the methodologies proposed by the $\mathrm{AOAC}^{18}$. Fiber content was measured using the detergent method according to Goering and Van Soest ${ }^{17}$. The carbohydrate content was calculated by differences in proteins lipid, ash, and moisture content. Atwater conversion factors were used to calculate the energy value: $4 \mathrm{kcal} / \mathrm{g}$ (protein), 4 $\mathrm{kcal} / \mathrm{g}$ (carbohydrates), and $9 \mathrm{kcal} / \mathrm{g}$ (lipids). All analyses were carried out in triplicate.

\section{Microbiological analysis}

Brazilian National Health Surveillance Agency (ANVISA) resolution $\mathrm{N}^{\circ} 12$ of January 2nd, 2001, which sets microbiological standards for foods, establishes analyses to determine the most probable number of total and fecal coliforms, mold, and yeast, and mandates absence of Salmonella spp. and Bacillus cereus for cereals compacted into bars or in other shapes ${ }^{20}$. The analyses were carried out according to the official methods by the APHA (American Public Health Association) ${ }^{21}$.

\section{Sensory analysis}

The study was approved by the Research Ethics Committee of the Brazilian National Health Council (resolution \#196/96, October $10^{\text {th }}$, 1996, protocol number 1.237.666).

Bars were evaluated regarding their acceptance ${ }^{22}$ using an unstructured nine-point hedonic scale (extremely liked to extremely disliked) pertaining to the attributes of appearance, color, flavor, texture, and overall impression. The evaluators also assessed the intention of purchasing the product using a five-point purchase attitude scale ${ }^{23}$. The samples were presented individually to the tasters on disposable plates coded with three random digits. One hundred and two untrained tasters of both genders between 18 and 63 years old took part in these analyses.

The acceptability index (Al) of each formulation was calculated using the following equation:

$\mathrm{IA}(\%)=\mathrm{Ax} 100 / \mathrm{B}$

Eq. 1

Where: $\mathrm{A}$ is the mean score for the product and $\mathrm{B}$ is the maximum score.

According to Dutcosky ${ }^{24}$, a product that reaches a percentage equal to or above $70 \%$ is considered accepted by the tasters.

\section{Shelf life estimation}

For the shelf life estimation (SLE) assay, the multicomponent snack bars were sealed in laminated BOPP/metalized BOPP packaging (water vapor permeability: 0.35 to $0.39 \mathrm{~g} / \mathrm{m}^{2} /$ day; oxygen permeability: 76.69 to $77.69 \mathrm{~g} / \mathrm{m}^{2} /$ day) and stored in desiccators with a saturated potassium chloride $(\mathrm{KCl})$ solution and an equilibrium of relative humidity of $82 \%$. Next, the desiccators were placed in a BOD (biochemical oxygen demand) oven at $30{ }^{\circ} \mathrm{C}$.

The snack bars were analyzed at $0,7,15,30,45$, and 60 days of storage for water activity, texture, instrumental color, and sensory and microbiological analyses following the aforementioned methodologies.

The results were plotted as a function of storage time in order to obtain linear models and their respective equations, which were used to calculate the SLE. The parameters whose initial behaviors were not linear were also plotted on a monologarithmic scale.

The SLE was calculated using Equation $2^{25}$.

$$
\operatorname{SLE}(\text { dias })=\mathrm{P}_{\mathrm{f}}-\mathrm{P}_{\mathrm{fi}} / \mathrm{k} \quad \text { Eq. } 2
$$

Where: $\mathrm{P}_{\mathrm{f}}$ is the threshold quality value of the parameter analyzed (water activity or sensory attributes), $P_{\text {fi }}$ is the value of the same parameters at time zero, and $\mathrm{k}$ is the reaction constant. The reaction constant was determined from the slopes of $\mathrm{a}_{\mathrm{w}}$ or sensory attributes versus the time of storage.

The sensory quality of the snack bars was assessed by a team of 12 tasters, who were selected for being regular consumers of cereal bars and for having experience in these analyses. The same team was used throughout the study in order to minimize possible errors among the analyses. The acceptance test used an unstructured $9 \mathrm{~cm}$ hedonic scale (extremely liked to extremely disliked) pertaining to the attributes of appearance, color, flavor, texture, and overall impression.

For SLE as a function of sensory data, the score of 5 
(did not like or dislike) was defined as the end of shelf life regarding the attributes studied or when aw reached the threshold value of 0.6. That score was used in the equations generated by each attribute to calculate the SLE ${ }^{22}$.

\section{Statistical analysis}

Analysis of variance (ANOVA) was used to analyze physicochemical characterization, instrumental texture, instrumental color, and sensory analysis and, in case of significant statistical difference ( $\mathrm{F}$ test) among the means of the formulations, they were compared by Tukey's test $(p<0.05)$.

Graphical representation was employed to visualize the sensory means of the samples and their behavior over the storage period.

The statistical calculations were performed using the software Excel version 2013 and Biostat version 5.026.

Pearson correlation ( $r$ ) analysis was performed between the sensory texture and water activity values so as to detect possible positive and/or negative correlations among the variables.

\section{RESULTS}

\section{Physicochemical characterization}

The results of the physicochemical characterization of the açaí- and cupuassu-flavored multicomponent snack bars are presented in table 2 .

\section{Sensory evaluation}

Table 3 shows the mean scores attributed by the tasters during the sensory acceptance test of the açaí- and cupuassu-flavored multicomponent snack bars.

The acceptability index (Al) for the attributes analyzed is presented in figure 1 .

\section{Shelf life estimation}

\section{Water activity, color, and shear stress}

Tables 4 shows the results of the parameters water activity, color $\left(\mathrm{a}^{*}, \mathrm{~b}^{*}\right.$, and $\left.\mathrm{L}^{*}\right)$, and shear stress of the açaíand cupuassu-flavored multicomponent snack bars over
60 days of storage at $30^{\circ} \mathrm{C}$.

The color parameters $\mathrm{a}^{*}, \mathrm{~b}^{*}$, and $\mathrm{L}^{*}$ for bars of both flavors did not significantly vary over the 60 days of storage.

\section{Sensory Analysis}

Tables 5 presents the results for the sensory attributes (appearance, color, flavor, texture, and overall impression) of the açaí- and cupuassu-flavored bars, respectively, over the 60 days of storage at $30{ }^{\circ} \mathrm{C}$.

Table 2. Physicochemical characterization of the açaí- and cupuassu-flavored multicomponent snack bars in wet basis.

\begin{tabular}{|lcc|}
\hline Determination & \multicolumn{2}{c|}{ Multicomponent snack bar } \\
\hline & Açaí flavor & Cupuassu flavor \\
\hline Moisture (\%) & $11.23 \pm 0.03 \mathrm{a}$ & $11.38 \pm 0.10 \mathrm{a}$ \\
Water activity & $0.43 \pm 0.01 \mathrm{~b}$ & $0.58 \pm 0.008 \mathrm{a}$ \\
Ashes (\%) & $0.92 \pm 0.03 \mathrm{a}$ & $0.99 \pm 0.05 \mathrm{a}$ \\
$\begin{array}{l}\text { Lipids (\%) } \\
\text { Proteins (\%) }\end{array}$ & $3.02 \pm 0.03 \mathrm{a}$ & $3.03 \pm 0.02 \mathrm{a}$ \\
Fibers (\%) & $1.06 \pm 1.09 \mathrm{~b}$ & $1.69 \pm 0.07 \mathrm{a}$ \\
$\begin{array}{l}\text { Carbohydrates } \\
\text { and others (\%) }\end{array}$ & $65.61 \pm 0.11 \mathrm{~b}$ & $67.59 \pm 0.16 \mathrm{a}$ \\
$\begin{array}{l}\text { Energy value } \\
\text { (kcal/100 g) }\end{array}$ & $447.50 \mathrm{a}$ & $435.66 \mathrm{~b}$ \\
\hline
\end{tabular}

Data presented as mean \pm standard deviation.

Means followed by the same letters on the same row do not differ according to Tukey's test at $5 \%$ probability.

Table 3. Mean scores attributed by the tasters during the sensory acceptance test of the açaí- and cupuassu-flavored multicomponent snack bars.

\begin{tabular}{lccccc|} 
Bar & \multicolumn{2}{c}{ Sensory parameters } & & & \\
& Appearance & Color & Flavor & Texture & $\begin{array}{c}\text { Overall } \\
\text { impression }\end{array}$ \\
\hline Açaí flavor & $7.11 \pm 1.78 \mathrm{a}$ & $7.19 \pm 1.85 \mathrm{a}$ & $7.16 \pm 2.00 \mathrm{a}$ & $7.26 \pm 1.74 \mathrm{a}$ & $7.14 \pm 1.77 \mathrm{a}$ \\
Cupuassu flavor & $7.20 \pm 1.70 \mathrm{a}$ & $7.34 \pm 1.66 \mathrm{a}$ & $7.63 \pm 1.69 \mathrm{a}$ & $6.86 \pm 1.99 \mathrm{a}$ & $7.38 \pm 1.60 \mathrm{a}$ \\
\hline
\end{tabular}

Data presented as mean \pm standard deviation.

Means followed by the same letters on the same row do not differ according to Tukey's test at $5 \%$ probability. 


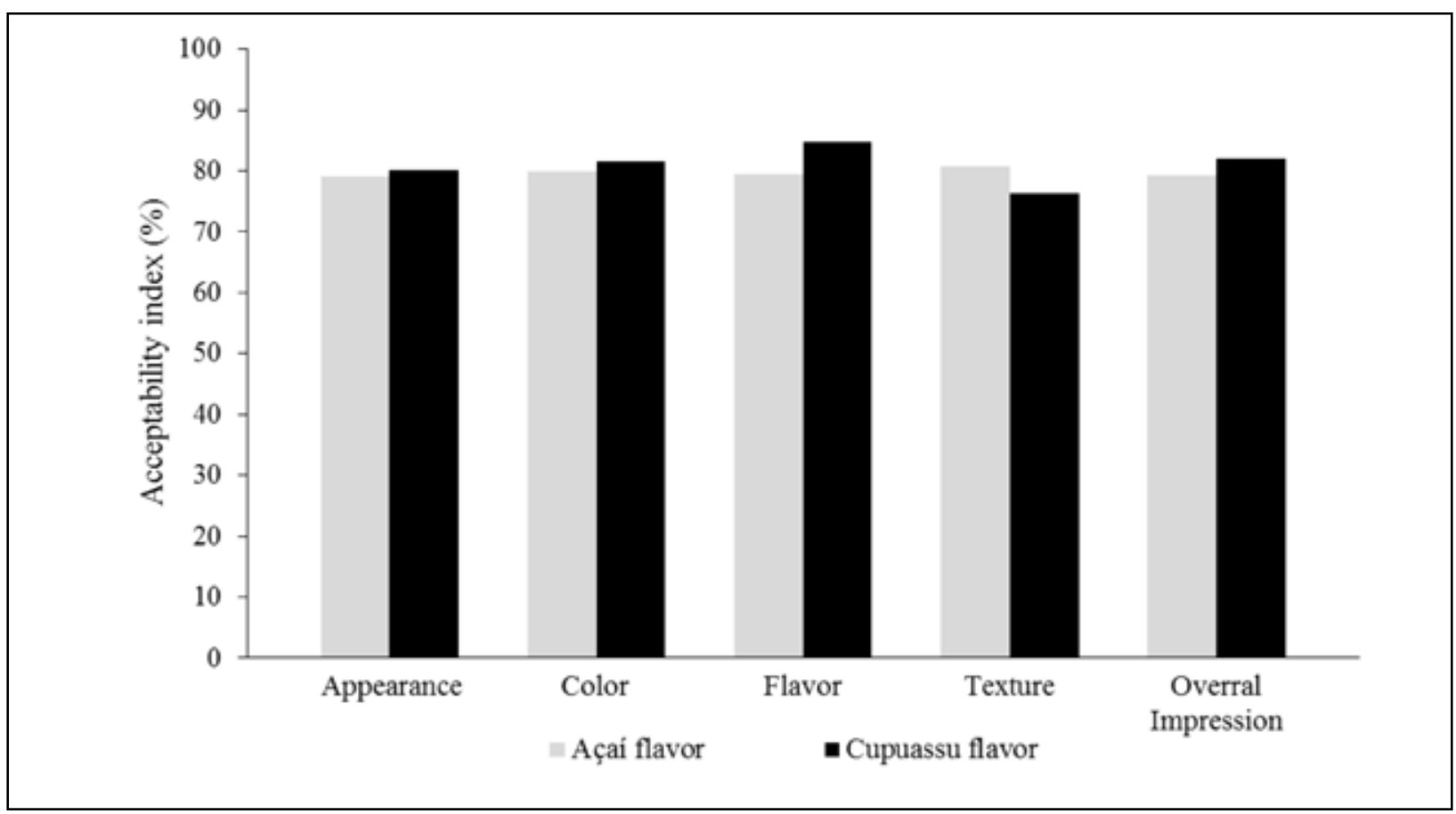

Figure 1: Acceptability index for the attributes appearance, color, flavor, texture, and overall impression of the açaí- and cupuassu-flavored multicomponent snack bars.

Table 4. Water activity, color, and shear stress of the açaí- and cupuassu-flavored multicomponent snack bars over 60 days at $30^{\circ} \mathrm{C}$.

\begin{tabular}{|lccccc|}
\hline \multicolumn{7}{|c}{ Açaí-flavored multicomponent snack bar } & & & \\
Time (days) & $\mathbf{a}_{\mathbf{w}}$ & $\mathbf{a}^{*}$ & $\mathbf{b}^{*}$ & $\mathbf{L}^{*}$ & Shear stress \\
\hline 0 & $0.44 \pm 0.002 \mathrm{f}$ & $38.82 \pm 2.44 \mathrm{a}$ & $2.26 \pm 0.70 \mathrm{a}$ & $2.99 \pm 0.98 \mathrm{a}$ & $54.14 \pm 6.74 \mathrm{ab}$ \\
7 & $0.48 \pm 0.002 \mathrm{e}$ & $40.07 \pm 1.93 \mathrm{a}$ & $2.90 \pm 0.95 \mathrm{a}$ & $5.12 \pm 1.04 \mathrm{a}$ & $66.89 \pm 3.42 \mathrm{a}$ \\
15 & $0.50 \pm 0.004 \mathrm{~d}$ & $37.55 \pm 1.69 \mathrm{a}$ & $2.29 \pm 0.69 \mathrm{a}$ & $4.22 \pm 0.48 \mathrm{a}$ & $42.36 \pm 7.20 \mathrm{bc}$ \\
30 & $0.54 \pm 0.001 \mathrm{c}$ & $38.54 \pm 3.28 \mathrm{a}$ & $2.72 \pm 1.13 \mathrm{a}$ & $4.67 \pm 1.16 \mathrm{a}$ & $58.02 \pm 4.56 \mathrm{ab}$ \\
45 & $0.56 \pm 0.001 \mathrm{~b}$ & $39.00 \pm 3.77 \mathrm{a}$ & $3.06 \pm 1.01 \mathrm{a}$ & $5.15 \pm 1.44 \mathrm{a}$ & $24.72 \pm 4.35 \mathrm{c}$ \\
60 & $0.60 \pm 0.05 \mathrm{a}$ & $36.70 \pm 2.75 \mathrm{a}$ & $2.03 \pm 0.84 \mathrm{a}$ & $4.18 \pm 1.14 \mathrm{a}$ & $46.34 \pm 5.22 \mathrm{~b}$ \\
& & & & & \\
\hline & & & & & \\
& & & & & \\
0 & & & & & \\
7 & $0.51 \pm 0.005 \mathrm{~d}$ & $56.15 \pm 4.83 \mathrm{a}$ & $1.44 \pm 0.45 \mathrm{a}$ & $11.85 \pm 1.51 \mathrm{a}$ & $35.43 \pm 3.82 \mathrm{~b}$ \\
15 & $0.52 \pm 0.001 \mathrm{~cd}$ & $55.56 \pm 5.46 \mathrm{a}$ & $1.41 \pm 0.52 \mathrm{a}$ & $13.46 \pm 1.65 \mathrm{a}$ & $74.15 \pm 9.44 \mathrm{a}$ \\
30 & $0.54 \pm 0.002 \mathrm{bc}$ & $55.41 \pm 2.98 \mathrm{a}$ & $1.33 \pm 0.62 \mathrm{a}$ & $12.53 \pm 1.93 \mathrm{a}$ & $30.65 \pm 4.91 \mathrm{~b}$ \\
45 & $0.55 \pm 0.001 \mathrm{~b}$ & $55.72 \pm 3.50 \mathrm{a}$ & $1.69 \pm 0.62 \mathrm{a}$ & $13.18 \pm 2.45 \mathrm{a}$ & $16.84 \pm 5.00 \mathrm{c}$ \\
60 & $0.61 \pm 0.001 \mathrm{a}$ & $52.24 \pm 5.70 \mathrm{a}$ & $1.38 \pm 0.88 \mathrm{a}$ & $12.23 \pm 2.92 \mathrm{a}$ & $15.67 \pm 4.36 \mathrm{c}$ \\
& $0.62 \pm 0.017 \mathrm{a}$ & $55.95 \pm 5.96 \mathrm{a}$ & $1.63 \pm 0.44 \mathrm{a}$ & $13.76 \pm 2.08 \mathrm{a}$ & $28.80 \pm 1.16 \mathrm{bc}$ \\
\hline
\end{tabular}

Data presented as mean \pm standard deviation.

Means followed by the same letters on the same column do not differ according to Tukey's test at $5 \%$ probability. 
Table 5. Mean sensory analysis results of the açaí- and cupuassu-flavored multicomponent snack bars over 60 days at $30{ }^{\circ} \mathrm{C}$.

\begin{tabular}{|c|c|c|c|c|c|}
\hline \multicolumn{6}{|c|}{ Açaí-flavored multicomponent snack bar } \\
\hline Time (days) & Appearance & Color & Flavor & Texture & Overall impression \\
\hline 0 & $7.95 \pm 0.89 a b$ & $8.23 \pm 0.84 a b$ & $8.32 \pm 0.67 \mathrm{a}$ & $8.07 \pm 1.26 a$ & $8.5 \pm 0.65 a$ \\
\hline 7 & $7.43 \pm 1.3 \mathrm{ab}$ & $8.05 \pm 1 \mathrm{ab}$ & $8.27 \pm 0.59 \mathrm{ab}$ & $7.9 \pm 1.22 \mathrm{a}$ & $8.17 \pm 0.71 \mathrm{a}$ \\
\hline 15 & $8.14 \pm 0.63 a$ & $8.34 \pm 0.77 a$ & $8.31 \pm 1.06 \mathrm{a}$ & $8.34 \pm 0.65 a$ & $8.44 \pm 0.51 \mathrm{a}$ \\
\hline 30 & $7.08 \pm 1.74 \mathrm{ab}$ & $7.31 \pm 1.44 a b$ & $7.51 \pm 1.82 \mathrm{abc}$ & $7.33 \pm 1.7 \mathrm{ab}$ & $7.63 \pm 0.62 \mathrm{ab}$ \\
\hline 45 & $7.01 \pm 1.34 \mathrm{ab}$ & $6.56 \pm 1.76 b$ & $6.6 \pm 1.48 \mathrm{bc}$ & $5.8 \pm 1.68 \mathrm{bc}$ & $6.7 \pm 0.8 b$ \\
\hline 60 & $6.25 \pm 1.38 b$ & $6.48 \pm 1.35 b$ & $6.13 \pm 0.86 c$ & $5.98 \pm 0.59 c$ & $6.68 \pm 1.31 b$ \\
\hline \multicolumn{6}{|c|}{ Cupuassu-flavored multicomponent snack bar } \\
\hline 0 & $8.05 \pm 0.99 a$ & $7.96 \pm 0.88 a$ & $8.63 \pm 0.48 a$ & $8 \pm 1.48 a$ & $8.15 \pm 0.91 a b$ \\
\hline 7 & $7.98 \mathrm{a} \pm 1.06 \mathrm{a}$ & $7.54 \pm 1.03 a$ & $8.32 \pm 0.59 a$ & $7.55 \pm 1.48 \mathrm{a}$ & $8.38 \pm 0.72 \mathrm{a}$ \\
\hline 15 & $7.51 \pm 2.21 \mathrm{a}$ & $8.31 \pm 0.69 a$ & $7.86 \pm 1.68 \mathrm{a}$ & $7.37 \pm 1.8 a$ & $8.27 \pm 0.55 a$ \\
\hline 30 & $7.48 \pm 1.68 a$ & $7.08 \pm 1.35 \mathrm{ab}$ & $7.52 \pm 2.19 a$ & $7.43 \pm 1.3 a$ & $7.62 \pm 0.81 \mathrm{abc}$ \\
\hline 45 & $7.08 \pm 1.49 a$ & $6.9 \pm 1.55 \mathrm{ab}$ & $6.78 \pm 1.84 a$ & $6.24 \pm 1.47 a b$ & $6.66 \pm 1.5 b c$ \\
\hline 60 & $7.18 \pm 0.39 a$ & $5.61 \pm 1.16 b$ & $7.15 \pm 1 \mathrm{a}$ & $5.24 \pm 1.47 b$ & $6.25 \pm 1.55 c$ \\
\hline
\end{tabular}

Data presented as mean \pm standard deviation.

Means followed by the same letters on the same row do not differ according to Tukey's test at $5 \%$ probability.

\section{Microbiology}

The açaí- and cupuassu-flavored multicomponent snack bars had counts of coliforms (at 35 and $40^{\circ} \mathrm{C}$ ), B. cereus, and Salmonella spp. within the limits established by the current legislation ${ }^{19}$. Mold and yeast counts, whose legal limits are not established for this type of product, varied between 39 and $55 \mathrm{CFU} / \mathrm{g}$ for the açaí-flavored bar and between 63 and $90 \mathrm{CFU} / \mathrm{g}$ for the cupuassu-flavored bar over the 60 days of storage.

\section{Calculating shelf life estimation}

The calculations of the shelf life estimation were performed for the açaí- and cupuassu-flavored multicomponent snack bars using the linear model equations of water activity and sensory attributes $(\mathrm{y})$ as a function of storage time $(\mathrm{x})$. The threshold values for water activity and sensory attributes considered were 0.6 and 5, respectively (Tables 6, 7 and 8 in Supplemental Content).

Considering the possibility that a decrease in mean texture values in the sensory analysis is related to the increase in water activity ${ }^{27}$, Pearson correlation coefficient ( $r$ ) was determined. Pearson correlation coefficient measures the degree of linear relation between two quantitative variables. The correlation was calculated between the sensory texture/ water activity variables of each multicomponent snack bar. The açaí-flavored bar showed a Pearson correlation coefficient of -0.854 and the cupuassu-flavored bar -0.963 .
According to results of correlation, there is a strong negative correlation between sensory texture and water activity for the two multicomponent snack bars, i.e., if the water activity values increase, the mean sensory texture scores decrease. Furthermore, the $p$-value associated with $\mathrm{t}$ (calculated) is below 0.05 , which suggests the probability the observed value of $r$ being casual is very small.

By inverting the analysis, i.e., determining the Pearson correlation coefficient between the water activity/texture values, it can be inferred that, in order to reach the quality threshold of this sensory attribute $(\leq 5)$, water activity may reach a maximum value of 0.65 .

\section{DISCUSSION}

\section{Physicochemical characterization}

According to ANVISA resolution $\mathrm{N}^{\circ} 359$ of December 23rd, 2003, the maximum energy value per cereal bar portion (one unit) is $150 \mathrm{kcal}^{28}$. Thus, the açaí- and cupuassu-flavored snack bars developed in the present research must weigh approximately 33 and $31 \mathrm{~g}$, respectively.

The mean moisture values observed were $11.2 \%$ for the açaí-flavored bar and $11.4 \%$ for the cupuassu-flavored one, with no statistical difference between them (Table 2). Those values are in accordance with ANVISA resolution $N^{\circ} 263$ of September 22nd, 2005, which established the limit of $15 \%$ moisture for cereal-based products ${ }^{29}$.

The initial moisture and moisture migration control is 
Table 6. Shelf life estimation of açaí- and cupuassu-flavored multicomponent snack bars considering the threshold water activity value of 0.6.

\begin{tabular}{|lcccc|}
\hline Flavor & Equations & $\mathbf{k}$ & SLE (days) & $\mathbf{R}^{2}$ \\
\hline Açaí & $y=0.0025 x+0.4556$ & 0.0025 & 58 days & 0.97 \\
Cupuassu & $y=0.0019 x+0.5075$ & 0.0019 & 49 days & 0.95 \\
\hline
\end{tabular}

Where: $y$ is the shelf life time and $x$ is the threshold water activity value of 0.6.

Table 7. Shelf life estimation of the açaí-flavored multicomponent snack bar considering the threshold value of sensory attributes of 5 .

\begin{tabular}{|lccc|}
\hline Attributes & \multicolumn{1}{c|}{ Equations } & SLE (days) & $\mathbf{R}^{\mathbf{2}}$ \\
\hline Appearance & $y=-0.0263 x+7.9976$ & 113 & 0.7809 \\
Color & $y=-0.0342+8.3893$ & 99 & 0.7809 \\
Flavor & $y=-0.0403 x+8.5787$ & 88 & 0.9504 \\
Texture & $y=-0.0431 x+8.3652$ & 78 & 0.8337 \\
Overall impression & $y=-0.0341 x+8.5795$ & 104 & 0.9094 \\
\hline
\end{tabular}

Where: $y$ is the shelf life time and $x$ is the threshold value of sensory attributes of 5.0.

Table 8. Shelf life estimation of the cupuassu-flavored multicomponent snack bar considering the threshold value of sensory attributes of 5 .

\begin{tabular}{|lccc|}
\hline Attributes & Equations & SLE (days) & $\mathbf{R}^{\mathbf{2}}$ \\
\hline Appearance & $y=-0.0158 x+7.9601$ & 187 & 0.8406 \\
Color & $y=-0.0367 x+8.1932$ & 87 & 0.7955 \\
Flavor & $y=-0.0277 x+8.4357$ & 126 & 0.8429 \\
Texture & $y=-0.042 x+8.071$ & 73 & 0.8971 \\
Overall impression & $y=-0.0372 x+8.1932$ & 94 & 0.919 \\
\hline
\end{tabular}

Where: $y$ is the shelf life time and $x$ is the threshold value of sensory attributes of 5.0.

essential to guarantee the quality and safety of foods. Water activity $\left(a_{w}\right)$ is a reference parameter for the production and storage of foods ${ }^{27}$. Food bars as a whole are prepared so as to maintain intermediate aw values, between 0.4 and $0.6^{3}$, and the control of this parameter is important to prevent microbial growth.

The water activity values of the açaí- and cupuassuflavored multicomponent snack bars were 0.43 and 0.58 , respectively. Those values are below 0.6 , which indicates low risk of microbial proliferation or pathogenic spoilage and long shelf life ${ }^{30}$.

The total lipid content significantly differed between the samples and were the highest in the açaí-flavored bars. That could be justified by the use of açaí pulp as an ingredient, which is about $4 \%$ lipids (wet basis), while cupuassu pulp has a mean lipid content of $1 \%$ (wet basis) ${ }^{31}$.

The mean lipid contents of different bars found in the literature ranged from 5.0 to $14.6 \% \%^{4,16,32,33}$. A comparison 
with the values obtained in this study (17.02 and 19.22\%) shows that the lipid content of the multicomponent snack bars are higher than those reported in the literature consulted.

The multicomponent snack bars of both flavors had similar protein content, with no statistical difference ( $p>0.05$ ), which is justified by the use of the Brazil nut in the same proportion for the two formulations.

The protein values found in the literature for different cereal bars ranged from 9.9 to $38.8 \% \%^{4,16,32,33}$, which can be explained by the different formulations employed in different studies and, consequently, different nutritional composition of the bars.

The carbohydrate content was 65.6 and $68 \%$ for the açaí- and cupuassu-flavored multicomponent snack bars, respectively, and were statistically different $(p<0.05)$. Carbohydrates were the compound found in highest concentration in bars, likely due to the use of ingredients rich in carbohydrates in the formulations such as tapioca flour and corn glucose syrup.

The açaí- and cupuassu-flavored snack bars had different energy values, higher in the former compared to the latter. This can be attributed to the higher lipid content of açaí pulp compared to cupuassu pulp.

As a result, the multicomponent snack bars developed in the present research can be classified as energetic given the high lipid and carbohydrate content. Therefore, bars can be recommended for physically active people and athletes in order to cover their caloric needs after training ${ }^{34}$.

\section{Sensory evaluation}

The multicomponent snack bars assessed did not differ statistically for any sensory parameter analyzed and obtained mean acceptance with scores between 6 and 8, which correspond to the categories "liked slightly" and "liked very much," respectively.

Carvalho et al. ${ }^{35}$ prepared three cereal bar formulations with chicha (Sterculia striata St. Hill. et Naud), monkey pot (Lecythis pisonis Camb.), and gurguéia nut (Dipteryx lacunifera Ducke) added to pineapple skin. The sensory test of those bars yielded mean scores between 6.8 and 7.3 for the attribute color, between 7.2 and 7.3 for texture, and between 6.9 and 7.0 for flavor, which are close to the results of the present study.

Silva et al. ${ }^{36}$, when studying bars prepared with pumpkin seeds at different concentrations, observed that, overall, the sensory parameter results ranged between 6 ("liked moderately") and 7 ("liked very much") for all attributes.

Padmashree et al. ${ }^{37}$ developed cereal bars rich in wheat, barley, and corn protein and different concentrations of isolated and concentrated soy protein. Those authors reported mean sensory analysis values of 7.7 for color, 7.6 for aroma, 7.8 for flavor, 7.7 for texture, and 7.9 for overall impression, which are similar to the ones found in the present study. Fonseca et al. ${ }^{38}$ prepared cereal bars with pineapple skin and reported mean values of $8.43,8.27,8.23$, and 8.33 for the attributes of appearance, flavor, texture, and overall impression, respectively, which are higher than the values found in the present study.

The acceptability scores and AI results of the products developed showed that all formulations had high acceptability since their Al values were above $75 \%$ for all attributes assessed.

The intention to purchase results confirmed the acceptance test results. Considering the scores of 4 and 5 as favorable responses to purchase, the açaí-flavored bar obtained the highest percentage of answers at level 5 of the scale, i.e., "would certainly buy." The second highest percentage was for level 4, "would possibly buy," at 29\% of the answers, which corresponds to a positive assessment of the purchase intentions. The cupuassu bar, in turn, had the highest percentage of scores at level 4 of the scale at $38 \%$ of the answers, followed by $31 \%$ of level 5 .

The purchase intention survey by Silva et al. ${ }^{39}$ for cereal bars made with passion fruit industrial residue at different proportions yielded mean scores corresponding to "would possibly buy" and "might/might not buy," which characterizes reasonable acceptance of the product presented, contrasting with the present study.

Fonseca et al. ${ }^{38}$, when studying cereal bars made with pineapple skin, observed that $67 \%$ of the tasters indicated they "would certainly buy" the product, 30\% "would probably buy" it, and 3\% "might buy" the bars, indicating good acceptability of the product, which matches the present study.

\section{Shelf life estimation \\ Water activity, color, and shear stress}

The results suggest the packaging used in the tests (BOPP/metallized BOPP) did not present a satisfactory barrier to water vapor permeability. Although that resin is considered a good barrier for water vapor, other parameters, such as thickness, might have impacted parameters since the film has not been developed specifically for this product. Micro gaps in sealing might also have influenced moisture absorption since the procedure was carried out manually, reproducing artisanal production at a pilot scale.

Although the shear stress test values significantly varied, that variation appeared random and showed no clear trend. Such oscillations could be attributed to the heterogeneity of the multicomponent snack bars since shear force is not always applied onto the same area of the sample being analyzed. Therefore, obtaining reliable shear stress results with products of this nature is still a challenge.

According to the literature, cereal bars have heterogeneous structure due to the shapes and sizes of their whole ingredients, as well as variations in thickness along their length ${ }^{40}$.

\section{Sensory Analysis}

The results for the sensory attributes (appearance, color, flavor, and texture) and overall acceptance had hedonic frequencies between level 5 and 8 ("neither liked nor disliked" and "liked very much"). Except for the appearance 
and flavor attributes of the cupuassu-flavored bar, the mean acceptance of all attributes assessed for bars of both flavors significantly decreased over the 60 days of storage, however, levels did not reach the rejection threshold (value $£ 5$ ).

It was also observed that texture was one of the most relevant parameters from the tasters' point of view since it was the attribute that first reached the lowest acceptance values for both bars. The loss of texture, in this case, can be attributed to the increase in water activity, shown in table 4.

In several SLE assays of cereal bars, texture was the attribute that had the greatest loss of acceptance over storage, matching the present study $y^{3,37}$.

\section{Calculating shelf life estimation}

The linear or semi-logarithmic models used to estimate shelf life did not correlate well with the experimental data of color and shear stress. Thus, representative equations of the behavior of the multicomponent snack bars could not be obtained during storage. In this case, water activity and sensory attribute data were used to calculate the shelf live estimation since those parameters showed a linear behavior with correlation coefficients close to 0.8 (Tables 6, 7 and 8 in Supplemental Content).

Among the parameters that showed linear behavior over storage, water activity and texture were the first to reach the quality threshold values established.

Given the storage temperature of $30{ }^{\circ} \mathrm{C}$ and water activity as the limiting parameter for shelf life, the SLE of the açaí-flavored multicomponent snack bar was 58 days and 49 days for the cupuassu-flavored one. Those times are compatible in their formulations with additive-free foods ${ }^{41}$.

\section{CONCLUSIONS}

The nutritional value of açaí- and cupuassu-flavored multicomponent snack bars is compatible with that of energy bars due to the significant content of lipids, proteins, and carbohydrates in their formulations. In this way, the bars prepared in the present study may be an alternative nutritive food product for athletes, as well as for people with celiac disease since they are gluten free.

The bars had high sensory acceptance. The overall impression acceptance indices were 79 and $82 \%$ for the açaí- and cupuassu-flavored bars, respectively.

Shelf life was defined as a function of water activity since this parameter was the first to reach the critical quality threshold during storage, thus significantly impacting sensory acceptance by the tasters regarding texture. The shelf life of the açaí-flavored bar was estimated as 58 days and that of the cupuassu-flavored bar, as 49 days. Those times are compatible with the expiration period of additive-free products.

Based only on the water activity data, new studies aiming to extend the shelf life of the final product could be carried out with other types of packaging.

Overall, the açaí- and cupuassu-flavored multicomponent snack bars are food options that add value to tapioca flour as well as promote and diversify the use of exotic fruits of the Amazon.

Acknowledgment. This work was supported by CNPq [grant number 407764/2013-5].

\section{REFERENCES}

1. Silva De Paula N, Gomes IDN, Aparecida HF, Souza IMD, Machado SRR, Stampini HMD. Characterization of cereal bars enriched with dietary fiber and omega 3. Rev Chil Nutr 2013; 40: 269-273.

2. Freitas DGC, Moretti RH. Caracterização e avaliação sensorial de barra de cereais funcional de alto teor protéico e vitamínico. Ciênc Tecnol Aliment 2006; 26: 318-324.

3. Lobato LP, Pereira AEIC, Lazaretti MM, Barbosa DS, Carreira CM, Mandarino JMGM, Grossmann MVE. Snack bars with high soy protein and isoflavone content for use in diets to control dyslipidemia. Int J Food Sci Nutrit 2012; 63: 49-58.

4. Pallavi BV, Chetana R, Ravi R, Reddy RY. Moisture sorption curves of fruit and nut cereal bar prepared with sugar and sugar substitutes. J Food Sci Technol 2013; 50: 1-7.

5. Izzo M, Niness K. Formulating nutrition bars with inulin and oligofructose. Cereal Foods World 2001; 46: 102-105.

6. Bishop L. Gluten-free protein bar options. J. Renal Nutrit. 2013; 23: c67-c69.

7. Chávez d., Ascheri J., Martins A., Carvalho C., Bernardo C., Teles A. Sorghum, an alternative cereal for gluten-free product. Rev Chil Nutr 2018; 45(2): 169-177.

8. Estévez V., Araya M. La dieta sin gluten y los alimentos libres de gluten. Rev Chil Nutr 2016; 43: 428-433.

9. Chisté RC, Silva PA, Lopes AS, Pena RS. (2012). Sorption isotherms of tapioca flour. Int J Food Sci Technol 2012; 47: 870-874.

10. Milde LB, Ramallo LA, Puppo MC. Gluten-free Bread Based on Tapioca Starch: Texture and Sensory Studies. Food Bioproc Technol 2012; 5: 888 -896.

11. Berno LI, Poeta PT, Maróstica Júnior MR (2010). Effects of selenium from the Brazil nut residue on the concentration of reduced glutathione (GSH) in wistar rat bloods. Alimentos e Nutrição 2010; 21: 231-239.

12. Santos OV, Lopes AS, Azevedo GO, Santos AC (2010). Processing of Brazil nut flour: characterization, thermal and morphological analysis. Ciênc Tecnol Aliment 2010; 30: 264-269.

13. Domingues AFN, Emmi DT, Barroso RFF, Mattietto RA. In: Pessoa JDC, Almeida, GH. Tecnologias para inovação nas cadeias Euterpe. Embrapa, Brasília, 2012.

14. Matos CB, Souza CN, Faria JC, Oliveira SJR, Santos LP, Sacramento CK. Características físicas e físico-químicas de cupuaçus de diferentes formatos. Rev Bras Ciênc Agrar 2008; 3: 35-45.

15. Khouryieh $\mathrm{H}$, Aramouni F. Effect of flaxseed flour incorporation on the physical properties and consumer acceptability of cereal bars. Food Sci Technol Int 2013; 19: 549-556.

16. Mendes NSR, Gomes-Ruffi CR, Lage ME, Becker FS, Melo AAM, Silva FA, Damiani C. Oxidative stability of cereal bars made with fruit peels and baru nuts packaged in different types of packaging. Braz J Food Sci Technol 2013; 33: 730736.

17. Mourão LHE, Pontes DF, Rodrigues MCP, Brasil IM, Cavalcante MTB (2012). Avaliação de barras de cereais de caju ameixa. Aliment Nutr 2012; 23: 287-295. 
18. Association of Official Analytical Chemists. Official methods of analysis of the AOAC. Horwitz W., Washington, 1997.

19. Goering HK, Van Soest PJ. Forage fiber analysis (Apparatus, reagents, procedures and some applications). USDA. Washington, DC, 1970.

20. Brasil. Resolução RDC N 12 de 2 de janeiro de 2001. Diário Oficial [da] República Federativa do Brasil. Poder Executivo. Brasília, DF, 12 de janeiro de 2001. Seção 1, p.48.

21. Vanderzant T, Splittstoesser EF. Compendium of methods for the microbiological examination of foods. 3. ed. American Public Health Association - APHA, Washington, 1992.

22. Stone H, Sidel JL (1993). Sensory Evaluation Practices, 2nd ed. Academic Press, London, 1993.

23. Meilgaard M, Civille GV, Carr BT. Sensory Evaluation Techniques. 3 ed. Boca Raton, New York, 1999.

24. Dutcosky SD. Análise Sensorial de Alimentos. 3 ed. Editora Universitária Champagnat, Curitiba, 2011.

25. Labuza T P. Shelf life dating of foods. Food and Nutrition Press, 1982.

26. Ayres M, Ayres Júnior M, Ayres DL, Santos AA. BIOESTAT. Aplicações estatísticas nas áreas das ciências biomédicas 2. Ong Mamiraua, Belém, 2007.

27. Maltini E, Torreggiani D, Venir E, Bertolo G. Water activity and the preservation of plant foods. Food Chem 2003; 82: 79-86.

28. Brasil. Resolução RDC n 359, de 23 de dezembro de 2003. Diário Oficial [da] República Federativa do Brasil. Poder Executivo, DF, de 26 de dezembro de 2003.

29. Brasil. Resolução RDC n 263, de 22 de setembro de 2005. Diário Oficial [da] República Federativa do Brasil. Poder Executivo, DF, de 23 de setembro de 2005.

30. Brasil. Ministério da Saúde. Alimentos Regionais Brasileiros. 2th ed. Ministério da Saúde, Brasília, 2015.

31. Jay JM. Microbiologia de Alimentos, 6 ed: Artmed, 2004.

32. Becker TS, Krüger RL. Elaboração de barras de cereais com ingredientes alternativos e regionais do Oeste do Paraná. Arquivos de Ciência e Saúde 2010; 14: 217-224.

33. Santos CT, Bonomo RF, Fontan RCl, Bonomo P, Veloso CM, Fontan GCR. Characterization and sensorial evaluation of cereal bars with jackfruit. Acta Scientiarum Technol 2011; 33, 81-85.

34. Norajit K, Gu BJ, Ryu GH. Effects of the addition of hemp powder on the physicochemical properties and energy bar qualities of extruded rice. Food Chem 2011; 129: 1919 $-1925$.

35. Carvalho MG, Costa JMC, Rodrigues MCP, Sousa PGM, Clemente E. Formulation and sensory acceptance of cerealbars made with almonds of chichá, sapucaia and gurguéia nuts. The Open Food Sci J 2011; 5: 26-30.

36. Silva JS, Marques TR, Simão AA, Corrêa AD, Pinheiro ACM, Silva RL. Development and chemical and sensory characterization of pumpkin seed flour-based cereal bars. Food Sci Technol 2014; 34: 346-352.

37. Padmashree A, Sharma GK, Govindaraj T. Development and Evaluation of shelf stability of flaxoat nutty bar in different packaging materials. Food Nut Sci 2013; 4: 538-546.

38. Fonseca RS, Del Santo VR, Souza GB, Pereira CAM. Elaboração de barra de cereais com casca de abacaxi. Arch Latinoamericanos Nut 2011; 61: 216-223.

39. Silva IQ, Oliveira BCF, Lopes AS, Pena RS. Obtenção de barra de cereais adicionada do resíduo industrial de maracujá. Aliment Nutr 2099; 20: 321-329.

40. Greve P, Lee YS, Meullenet JF, Kunz B. Improving the prediction for sensory texture attributes for multicomponent snack bars by optimizing instrumental test conditions. (Report). J Texture Studies 2010; 41: 358 - 380.

41. Paiva CL, Queiroz VAV, Rodrigues JAS. Estudos sensoriais para determinação da vida de prateleira de barra de cereais com pipoca de sorgo. Rev Bras Milho Sorgo 2012; 11: 302311. 